\title{
Impact of Some Ecological Factors on Fecal Contamination of Drinking Water by Diarrheagenic Antibiotic-Resistant Escherichia coli in Zagazig City, Egypt
}

\author{
Ahmed Elsadek Fakhr, Maha Kamal Gohar, and Amal Hassan Atta \\ Microbiology and Immunology Department, Faculty of Medicine, Zagazig University, Zagazig, Egypt \\ Correspondence should be addressed to Ahmed Elsadek Fakhr; ahmed_fakhr@yahoo.com
}

Received 21 January 2016; Revised 2 July 2016; Accepted 4 August 2016

Academic Editor: Ravinder Nagpal

Copyright (C) 2016 Ahmed Elsadek Fakhr et al. This is an open access article distributed under the Creative Commons Attribution License, which permits unrestricted use, distribution, and reproduction in any medium, provided the original work is properly cited.

\begin{abstract}
Fecal contamination of drinking water is a major health problem which accounts for many cases of diarrhea mainly in infants and foreigners. This contamination is a complex interaction of many parameters. Antibiotic resistance among bacterial isolates complicates the problem. The study was done to identify fecal contamination of drinking water by Diarrheagenic AntibioticResistant Escherichia coli in Zagazig city and to trace reasons for such contamination, three hundred potable water samples were investigated for E. coli existence. Locations of E. coli positive samples were investigated in relation to population density, water source, and type of water pipe. Sixteen E. coli strains were isolated. Antibiotic sensitivity was done and enterotoxigenic, enteropathogenic, and enterohaemorrhagic virulence genes were investigated by PCR. Probability of fecal contamination correlated with higher population density, with increased distance from Zagazig water plant, and with asbestos cement water pipes. Resistance to at least one antimicrobial drug was found in all isolates. Virulence genes were detected in a rate of $26.27 \%, 13.13 \%, 20 \%, 6.67 \%$, and $33.33 \%$ for LT, ST, stx1, stx2, and eae genes, respectively. This relatively high frequency of fecal contamination points towards the high risk of developing diarrhea by antibiotic resistant DEC in low socioeconomic communities particularly with old fashion distribution systems.
\end{abstract}

\section{Introduction}

Waterborne diseases are a significant public health issue, and many originate from contact with water contaminated with human fecal material [1]. Each year, more than 800,000 children younger than 5 years of age die from diarrhea, mostly in developing countries, which accounts for $11 \%$ of children deaths under the age of five years [2].

There are over 100 different types of bacteria, protozoa, and viruses that can be transmitted through contaminated water with numerous outbreaks which have been reported. Diarrheagenic E. coli (DEC) are among the most common etiologic agents of diarrhea from water origin. They are classified according to their virulence factors and other phenotypic traits into enterotoxigenic E. coli (ETEC), enteropathogenic E. coli (EPEC), Vero toxin/Shiga toxinproducing E. coli (VTEC/STEC) or enterohaemorrhagic $E$. coli (EHEC), enteroinvasive E. coli (EIEC), diffusely adherent E. coli (DAEC), and enteroaggregative E. coli (EAEC). All are known to be endemic in essentially all developing countries [3].

Similar to many other diarrheal diseases, ingestion of contaminated food and water can result in diarrhea due to DEC $[4,5]$. Whenever inadequate drinking water and poor sanitation are found, DEC represent a major cause of diarrheal illness. Different sources of waters including drinking water, rivers, swimming pools, surface waters, and lakes have been found to harbor these organisms [6] and transmission can occur while drinking, bathing, and/or using water for food preparation [7]. Among the six known 
Diarrheagenic Escherichia coli ETEC, EHEC and EPEC are the most significant, with higher impact on countries of the developing world [8].

ETEC is the one which can produce heat labile and/or heat stable enterotoxins in addition to colonization factors which enable the organisms to colonize the small intestine and make diarrhea. Both enterotoxins and colonization factors differentiate ETEC from other categories of Diarrheagenic E. coli [7]. EPEC is known as a main cause of diarrhea among children less than 2 years of age particularly in the developing world. It can be defined as intimin (encoded by eae gene) containing E. coli bacteria that have the ability to form the distinctive histopathology attachment and effacing (A/E) lesions on intestinal cells but do not own the stx gene.

Shiga toxin-producing/enterohaemorrhagic E. coli (STEC/ EHEC) or Vero toxin-producing E. coli (VTEC) was recognized in 1983 as a cause of hemorrhagic colitis (HC) with a recent large outbreak identified in Germany $[9,10]$.

According to the water-quality standards provided by WHO, the number of $E$. coli or thermotolerant bacteria should be nil in a $100 \mathrm{~mL}$ drinking water sample [11]. However, some standards allow the existence of ten coliforms/ $100 \mathrm{~mL}$ potable water [12]. Existence of coliform bacteria within a distribution system is a multifaceted interaction of physical, chemical, processing, and manufacturing aspects [13]. Distance from treatment place [14, 15], type, leaks, and breaks in the water pipe systems [16, 17], seasonal variation [18], and other environmental factors [19] were investigated and many were proved to have an influence on drinking water fecal contamination.

To monitor procedure of water treatment and disinfection, the total bacterial or heterotrophic plate counts can be useful. In addition, it can be used to verify the integrity of distribution systems, cleanliness, and existence of biofilms [18].

Zagazig city (Figure 1) is the capital of Sharkia Governorate, located $100 \mathrm{~km}$ north east to Cairo and one of the biggest cities in Egypt in terms of population. The city is supplied by drinking water from different sources including surface and ground water. The old water distribution and sewage disposal systems in addition to poor sanitation facilities are frequent in communities like Zagazig. This may predispose to spread of fecal bacteria to surface and drinking water and hence lead to outbreaks of diarrhea in such communities.

In addition, drinking water pollution by fecal coliform bacteria harboring resistance genes is a water-quality issue of national scope and importance. E. coli can be considered as an important vehicle for the spread of resistance genes due to its plenty in such environments with a high risk of transfer from environment to human pathogens [20].

The objectives of this work were to determine the prevalence and reasons of fecal contamination of drinking water in Zagazig city, to determine the antibiotic resistance profile of the isolated E. coli and to recognize the presence of some Diarrheagenic E. coli (DEC) virulence genes among these isolates.

\section{Material and Methods}

Zagazig city is divided into 3 governmental districts (Figure 2). A total of 300 potable water samples were collected over the year 2011 from different sites chosen randomly among the mentioned previous districts, with respect to the population of each district. In addition, water samples from the main water plant and underground wells in the city were collected before entering the distribution system.

Maps for districts, water sources, population density, and water distribution system network of different regions in city were made according to data provided by Geographical Information System of Potable water and Sanitation Company of Zagazig city.

Tap water samples were aseptically collected and checked for fecal contamination by $E$. coli as described by Ram et al. [21]. Membrane filtration technique was used for one hundred $(\mathrm{mL})$ volume from each site. Each membrane filter was aseptically cut into four pieces, transferred into a $25 \mathrm{~mL}$ MacConkey broth, and incubated for $24 \mathrm{hr}$. Subculture was done on eosin methylene blue (EMB) agar. Presumptive E. coli colonies with blue black metallic sheen on EMB were selected and confirmed as E. coli using routine biochemical assays.

2.1. Antimicrobial Susceptibility Determination. Isolated E. coli were tested against 8 antibiotics from six classes: $\beta$-lactams (ampicillin, $10 \mu \mathrm{g} / \mathrm{disc}$ ); aminoglycosides (amikacin, $10 \mu \mathrm{g} /$ disc; gentamicin, $10 \mu \mathrm{g} /$ disc); cephalosporins (cefotaxime, $30 \mu \mathrm{g} / \mathrm{disc}$ ); fluoroquinolones (ciprofloxacin, $5 \mu \mathrm{g} / \mathrm{disc}$; norfloxacin, $10 \mu \mathrm{g} / \mathrm{disc}$ ); phenicols (chloramphenicol, $30 \mu \mathrm{g} /$ disc); and tetracyclines (tetracycline, $30 \mu \mathrm{g} /$ disc). These tests were performed using an agar-diffusion method following Clinical and Laboratory Standards Institute breakpoints [22].

2.2. Virulence Genes Detection. For the determination of virulence genes, genomic DNA from E. coli isolates was extracted using G-spin Genomic DNA Extraction Kit (Bacteria) (iNtRON Biotechnology) following manufacturer's protocol. Bacterial total DNA from isolates was prepared for PCR by boiling technique as previously described by Zhao et al. [23]. Virulence genes of ETEC, EPEC, and EHEC were screened using the primers described by Ram et al. [24]. PCR primer sequences, their related gene targets, and expected amplification products size are shown in Table 1.

For amplification Maxime PCR PreMix kit (i-Taq) (iNtRON Biotechnology) was used. A typical $20 \mu \mathrm{L}$ PCR reaction assay mixture was accomplished by addition of $0.4 \mu \mathrm{M}$ from each primer, $4 \mu \mathrm{L}$ template DNA to the premix tubes containing 2.5 units of Taq DNA polymerase, $1 \mathrm{x}$ reaction buffer $2.5 \mathrm{mM}$ of each dNTP, and 1x gel loading dye. Distilled water was added to bring the final volume to $20 \mu \mathrm{L}$.

PCR amplification was performed in Biometra thermal cycler T3000 (Biometra, Westburg BV, Netherlands). Using specific primers, genomic DNA was used for PCR amplification of stxl, stx2, and eae A genes where total DNA was used for LT1 and ST1 genes with the following cyclic conditions (stx1: $94^{\circ} \mathrm{C} \mathrm{min}, 48^{\circ} \mathrm{C} 1 \mathrm{~min}$, and $72^{\circ} \mathrm{C} 1 \mathrm{~min}$; stx2: $94^{\circ} \mathrm{C} 1 \mathrm{~min}, 45^{\circ} \mathrm{C} 1 \mathrm{~min}$, and $72^{\circ} \mathrm{C} 1 \mathrm{~min}$; eae A: $94^{\circ} \mathrm{C} 1 \mathrm{~min}$, 


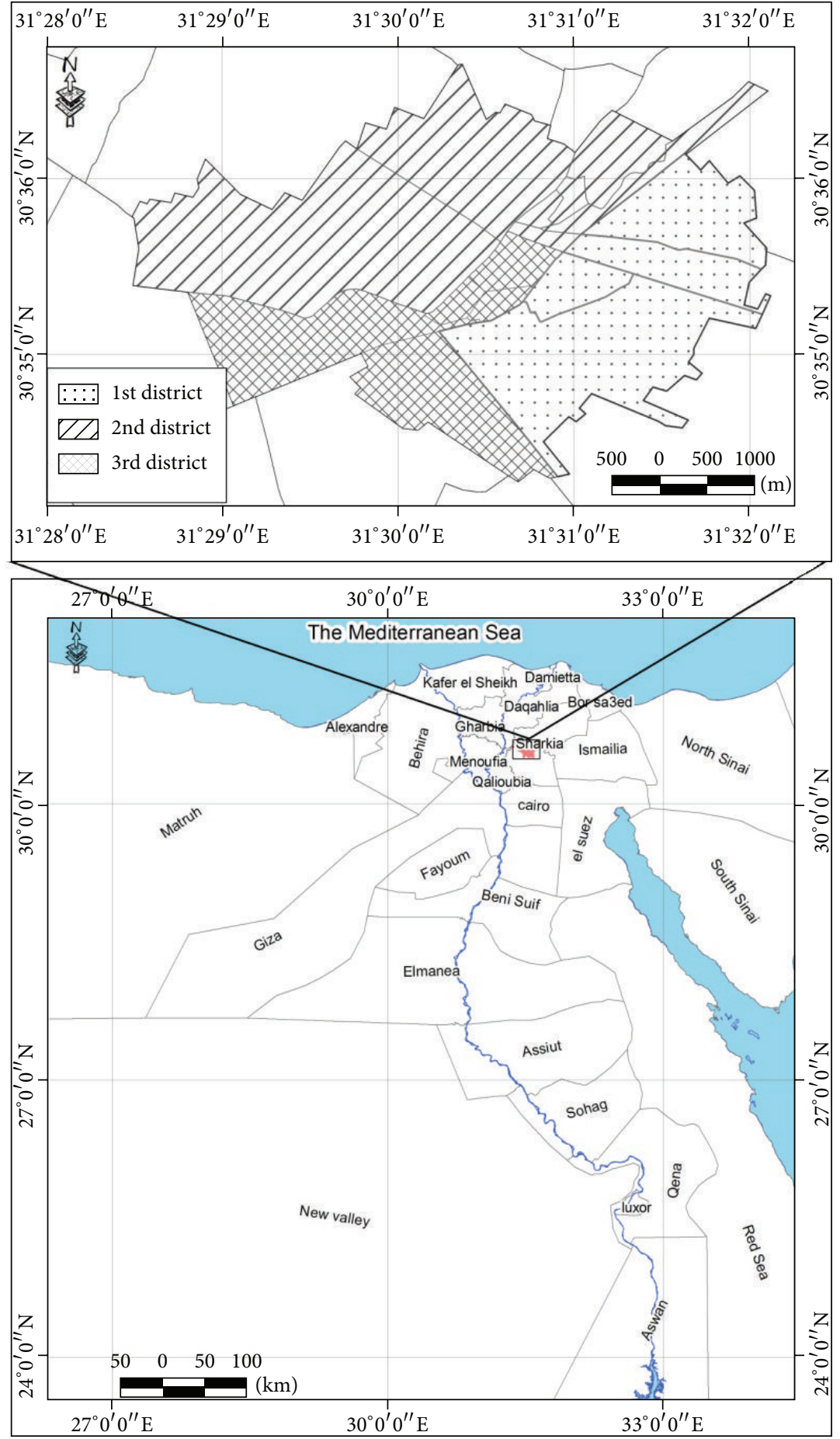

FIgURE 1: Location of Zagazig city in Arab Republic of Egypt (ARE) and its 3 districts.

$44^{\circ} \mathrm{C} 1 \mathrm{~min}$, and $72^{\circ} \mathrm{C} 1 \mathrm{~min}$; $\mathrm{LT} 1: 94^{\circ} \mathrm{C} 1 \mathrm{~min}, 42^{\circ} \mathrm{C} 1 \mathrm{~min}$, and $72^{\circ} \mathrm{C} 1 \mathrm{~min}$; and ST1: $94^{\circ} \mathrm{C} 1 \mathrm{~min}, 49^{\circ} \mathrm{C} 1 \mathrm{~min}$, and $72^{\circ} \mathrm{C} 1 \mathrm{~min}$ ). PCR products were visualized and analyzed using agarose gel electrophoresis under UV illumination.

Statistical analysis was done using SPSS (Version 20.0). Intergroup comparison was performed using Chi-square test. $P$ value $<0.05$ was considered statistically significant.

\section{Results}

In present study, a total of 90 public water supply samples from the 1st district of Zagazig, 120 from the 2nd district, and 90 from the 3rd district, in addition to water samples before entering the distribution system were taken. All water samples were analyzed by MFT and subcultured on 
TABLE 1: PCR primer sequences, their related gene targets, and expected amplification products size.

\begin{tabular}{lcc}
\hline Virulence genes & Primer sequence $\left(5^{\prime}-3^{\prime}\right)$ & Product size $(\mathrm{bp})$ \\
\hline Heat labile toxin 1 (LT1) & F: TTACGGCGTTACTATCCTCTCTA & 322 \\
\hline Heat stable toxin 1 (ST1) & F: CTTTCCCCTCTTTTTAGTCAG \\
& R: TAACATGGAGCACAGGCAGG & 175 \\
Shiga like toxin 1 (stxl) & F: CTGCCGGACACATAGAAGGAAACT & 267 \\
\hline Shiga like toxin 2 (stx2) & F: AGAGGGGATTTCGTACAACACTGG \\
\hline Intimin (eae A) & R: GCGTCATCGTATACACAGG \\
\hline
\end{tabular}

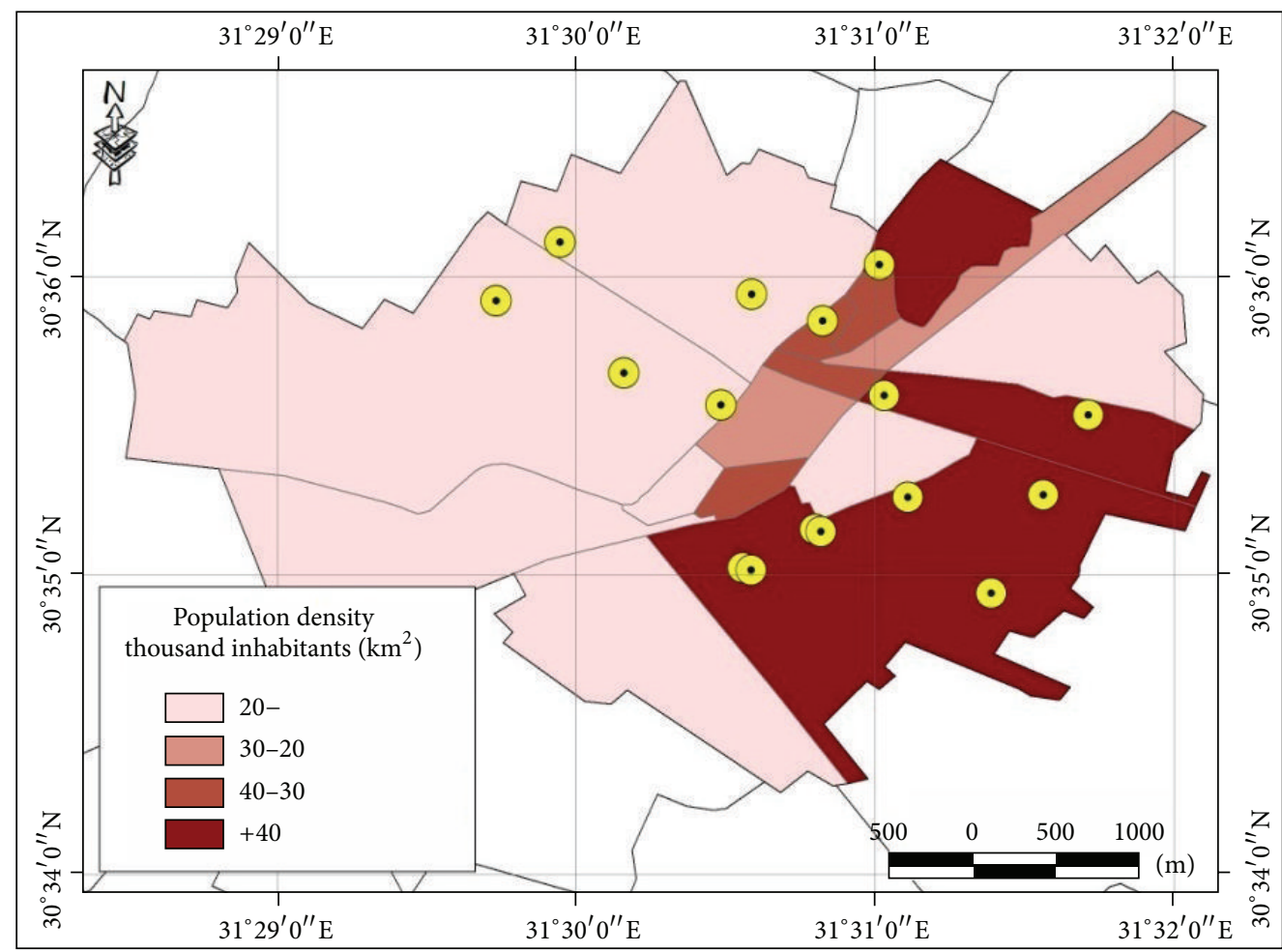

FIGURE 2: The positive E. coli isolates in relation to population density of different regions of Zagazig city.

MacConkey broth and EMB for isolation of coliform and $E$. coli.

Total coliform count was nil in all water samples collected before joining the distribution system from all sources.

In the 1st district, $20(22.2 \%)$ water samples were found to be contaminated by coliform bacilli. Out of these $9(10.0 \%)$ were found to harbor E. coli. In the 2nd district, 16 (13.3\%) water samples were found to be contaminated by coliform. Out of these 7 (5.83\%) were found to harbor E. coli. In the 3rd district, no coliforms were obtained.

The percentage of noncoliform isolates ranged from $6.66 \%$ in the third district to $18.3 \%$ in the second district (Table 2).
There was an increase in incidences of total coliform $(P=$ $0.05)$ and E. coli $(P=0.03)$ isolates in spring months with peak in March (Table 3).

By studying the maps for population density of the city, it was found that $11(68.75 \%)$ E. coli were isolated from areas with highest population density. Only 3 samples (18.75\%) were isolated from areas of intermediate density and 2 samples (12.5\%) from lower population density (Figure 2).

It was observed that all isolates were away from the main water plant in the western area of Zagazig (Figure 3).

The main types of water distribution peripheral system in Zagazig are the polyvinyl-chloride plastic type (PVC) and the asbestos cement types. It can be noticed through this map that 
TABLE 2: Distribution of noncoliforms, coliforms, and E. coli among the three districts.

\begin{tabular}{lccccc}
\hline District & Total number of samples & $\begin{array}{c}\text { Total isolates } \\
\text { Number (\%) }\end{array}$ & $\begin{array}{c}\text { Noncoliforms } \\
\text { Number (\%) }\end{array}$ & $\begin{array}{c}\text { Total coliforms } \\
\text { Number (\%) }\end{array}$ & $\begin{array}{c}\text { E. coli } \\
\text { Number (\%) }\end{array}$ \\
\hline First district & 90 & $30(33.3)$ & $10(11.1)$ & $20(22.2)$ & $9(10.0)$ \\
Second district & 120 & $38(31.66)$ & $22(18.3)$ & $6(13.3)$ & $7(5.83)$ \\
Third district & 90 & $6(6.66)$ & $38(12.66)$ & $36(12.0)$ & $0(0.0)$ \\
\hline Total & 300 & $74(24.66)$ & & $16(5.33)$ \\
\hline
\end{tabular}

TABLE 3: Distribution of positive coliform and E. coli isolates among seasons of the year.

\begin{tabular}{|c|c|c|c|c|c|}
\hline Seasons & Spring & Other seasons & Test of significance & $P$ value & Sig. \\
\hline Number/percentage of coliform positive samples & $26(17.1 \%)$ & $10(6.75 \%)$ & $\chi^{2}=3.84$ & $P=0.05$ & S. \\
\hline Number/percentage of E. coli positive samples & $14(9.2 \%)$ & $2(1.35 \%)$ & $\chi^{2}=4.59$ & $P=0.03$ & S. \\
\hline
\end{tabular}

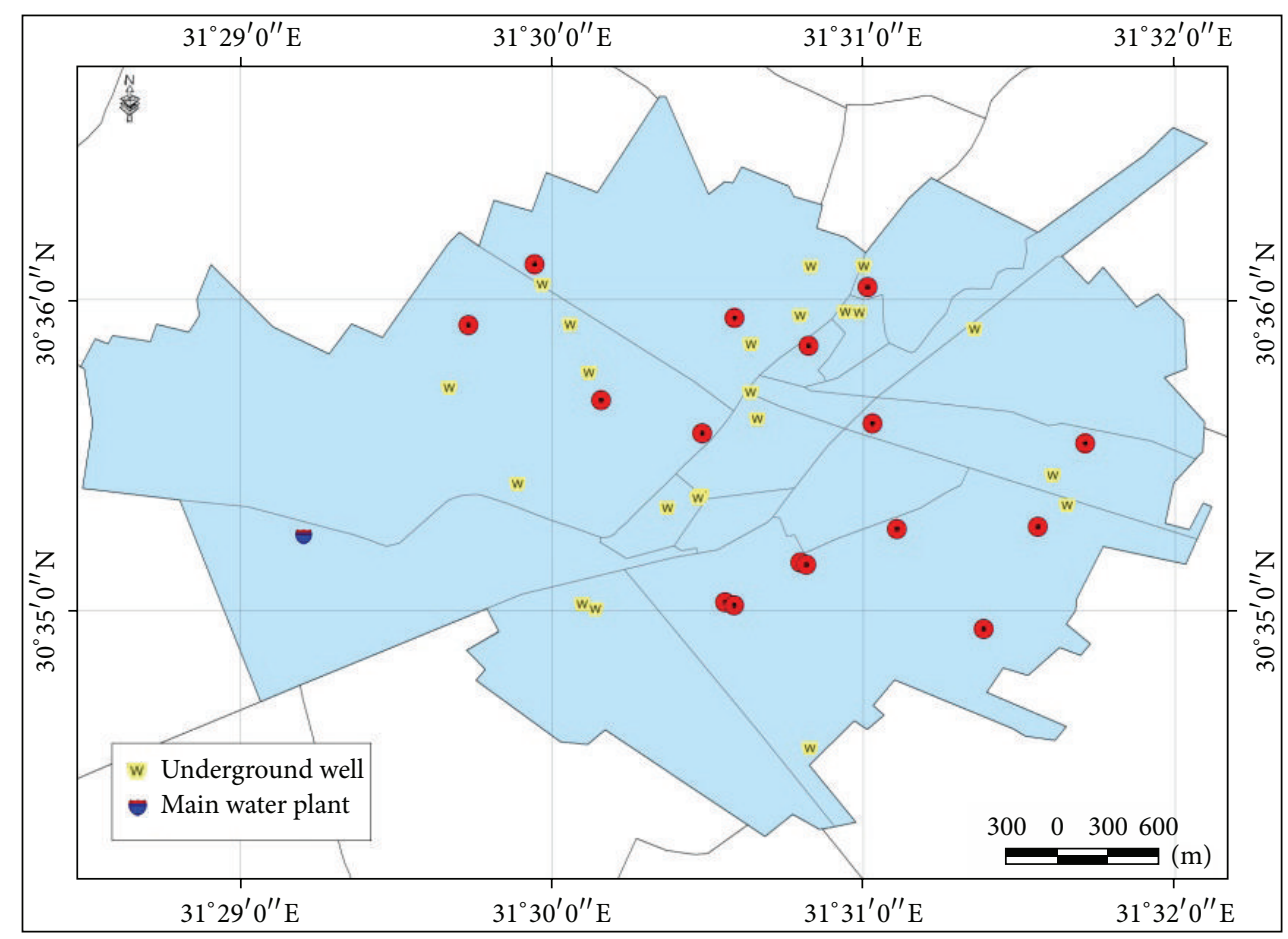

FIgURE 3: The positive E. coli isolates in relation to water sources in different regions of Zagazig.

10 positive samples for $E$. coli fall in the area of the asbestos cement type. Two samples fall in the area of PVC pipes. Four samples fall in areas with nonclarified type of pipes (Figure 4 ).

In this study $10 / 16(62.5 \%)$ of E. coli exhibited resistance to three or more antimicrobial agents.

E. coli isolates showed high resistance to cefotaxime and tetracycline (62.5\%) followed by ampicillin (50\%). Reduced susceptibility was observed with chloramphenicol $(37.5 \%)$, followed by gentamycin (25\%), norfloxacin (12.5\%), and cefotaxime (12.5\%). Highest sensitivity was found with amikacin (75\%), gentamycin (75\%), and norfloxacin (75\%) followed by ciprofloxacin $(62.5 \%)$.

As regards virulence genes detection by PCR, eight isolates $(50.0 \%)$ were found to harbor at least one virulence gene. Four isolates had (LT) gene; 2 of them carry (ST) gene.
Three E. coli isolates were found to have (stx1); one of them carries (stx2) gene as well. Five isolates carried eae A gene (Table 4).

\section{Discussion}

Globally, near 800 million people have no access to improved water sources and about 2.5 billion people do not have access to satisfactory sanitation [25]. Outbreaks of waterborne diarrheal diseases still have a serious health threat worldwide.

A better knowledge of the prevalence, ecology and distribution of fecal contamination in drinking water sources could be an important start for development of strategies to reduce the associated public health risk. 


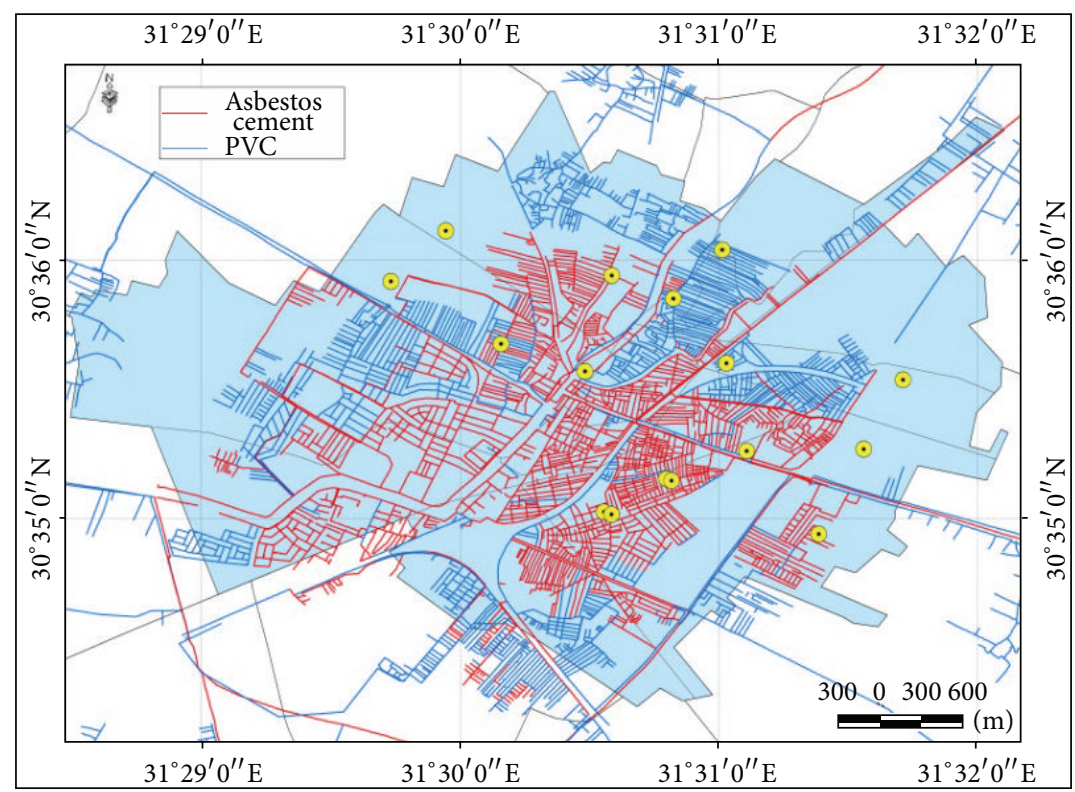

FIGURE 4: The positive E. coli isolates in relation to Zagazig water network with its different materials of construction.

TABLE 4: Virulence genes among E. coli isolates in both districts.

\begin{tabular}{lcccccc}
\hline \multirow{2}{*}{ Gene } & \multicolumn{2}{c}{ Total $(n=15)$} & \multicolumn{2}{c}{ First district } & \multicolumn{2}{c}{$\begin{array}{c}\text { Second district } \\
(n=8)\end{array}$} \\
& Positive & $\%$ & Positive & $\%$ & Positive & $\%$ \\
\hline LT gene & 4 & 26.27 & 2 & 25.0 & 2 & 28.57 \\
ST gene & 2 & 13.13 & 0 & 0.00 & 2 & 28.57 \\
stx1 gene & 3 & 20.0 & 2 & 25.0 & 1 & 14.28 \\
stx2 gene & 1 & 6.66 & 1 & 12.5 & 0 & 0 \\
eae gene & 5 & 33.33 & 3 & 37.5 & 2 & 28.57 \\
\hline
\end{tabular}

Zagazig city is the capital of Sharkia Governorate and one of the biggest cities in Egypt in terms of population which is near 500,000 with a population density over $60,000 \mathrm{inh} . / \mathrm{km}^{2}$ in many of its regions.

The city has two sources of drinking water, surface and ground water. The chief supply of drinking water is Zagazig water plant located in the western area (3rd district). However, the increasing population of the city exceeds the capacity of the station and necessitates the assistance by a number of ground water wells. About 22 ground water wells are working now in the city and responsible for about $50 \%$ of the city water needs (Figure 3).

As the networks of water pipes in Zagazig are continuous, it was difficult to determine which regions are supplied by each well or which is supplied solely by the main station.

Total coliform prevalence among the 300 tap water samples taken from the city was $12 \%$. Out of them $5.33 \%$ were $E$. coli. This was less than the prevalence detected by Ozgumus et al. [20] who found that $30 \%$ of their tap water samples isolated from coastal region of Northern Turkey are contaminated by coliform bacteria. This may be attributed to the larger study area which included rural and agricultural regions unlike our study which was restricted to the city.

In another study in India, Patel et al. [26] found that all the potable water samples exceeded the standard permissible limits. They explained this high prevalence by rainy environment in the area of study which saves warm humid conditions supporting microbial growth.

The interesting point is that a highly significant difference in the prevalence of total bacterial isolates, total coliform, and E. coli between the three districts of Zagazig was found ( $P$ value $=0.001,0.004$, and 0.06 , resp.) with the least prevalence recorded in the 3rd district. Reasons for such finding were traced and many explanations were suggested.

First, the 3rd district is the one in which the main water plant is found, which makes most areas in this district supplied mainly by treated water from the plant with less chance to be contaminated at its way. Also in the areas near the main water plant the concentration of terminal chlorine is the highest; therefore E. coli which could contaminate this water are nonviable or sublethally injured and may not be detected by culture on selective media; however they are metabolically active [27].

Second, the 1st district which had the highest prevalence of pollution is the most far from the main plant water station as shown in (Figure 3). Moreover, this district is the area of highest population density that makes the individual share of services including safe water supply and sewage disposal is less and hence decreases the quality of these services (Figure 2).

A similar finding was noticed in an Egyptian study by Abu-Elyazeed and his colleagues, where the incidence of $E$. coli diarrhea increased in household crowding and decreased with the presence of sanitary latrine [28]. 
Also, Cheesbrough documented that the larger the population served, the longer the distribution system and therefore the greater the risk of contamination [29].

Third, the city has 2 main types of water pipes (Figure 4): the asbestos cement pipes and the polyvinyl-chloride plastic (PVC) type. The asbestos cement type is the one which was used for more than 30 years but now it is replaced with PVC for its known health risks. It was noticed that most of $E$. coli isolates were detected from sites where the asbestos cement type is the most prevalent. This could be explained by a 2012 study that illustrated that PVC has a lower water main break rate than cast iron, ductile iron, steel, asbestos cement, and concrete [16]. Also, the life span of asbestos cement type was exceeded or about to be exceeded in many of the city regions what makes it more susceptible for breakage and leaks. The surrounding environment could also age the asbestos cement pipes prematurely and increased the rate of leaks and bursts [17].

The total bacterial isolates were 30 out of 90,38 out of 120 , and 6 out of 90 in the 1st, 2nd, and 3rd districts, respectively. This may indicate that water from 3 rd district has better treatment, disinfection, and integrity of distribution systems than the 1st and 2nd.

Although 3 samples were taken from each site at different times among the year, E. coli was isolated twice from only two of these sites. This means that contamination was an accidental event that is affected by different factors [13]. Absence of $E$. coli growth on repeating of sample from the same site can be attributed to either interference by the presence of high numbers of background heterotrophic bacteria or the inability of membrane filtration technique (MFT) to recover stressed or injured coliforms [30].

With regard to seasonality, the 300 water samples were taken all over the year but it was noticed that there is significant increase in the incidence of positive coliforms and E. coli samples in the spring with peak in March (Table 3). This is also matching with findings reported that DEC diarrhea and asymptomatic colonization are most common during warm periods of the year [28, 31,32].

It was also reported that DEC contamination remains endemic all year with two peaks, one at the spring and the other in the autumn months $[33,34]$. As the temperature rises when spring begins after winter months, bacterial growth increases and this continues in the summer months [35]. Such seasonality could be initiated by atmospheric temperature and extended by other ecological factors.

However, in this study the continuity of this high incidence in summer months was not observed. This may be attributed to the relatively dry nonrainy nature of summer climate in the location of study unlike that found in areas of other studies which have humid rainy climate in this season.

Increased utilization of antimicrobial agents in farming and animal husbandry, beside its use in medical therapy, has resulted in selective stress on environmental bacteria [36]. Therefore antibiotic resistance grows to be a notable problem in bacteria from aquatic environments including drinking water [37-40].

In this study, all of the isolated E. coli $(n=16)$ were resistant to at least one antimicrobial agent and 10 out of the 16 samples (62.5\%) displayed resistance to three or more antimicrobial agents. This incidence of multidrug-resistant strains is near to that detected by Ram et al. [24] who found that $57.8 \%$ of $E$. coli strains isolated from surface water samples were multidrug-resistant. However, a relatively lower incidence was reported by Toroglu et al. [41], who found that $40 \%$ of the coliforms isolated from water samples in Turkey were multidrug-resistant.

Almost similar resistance pattern was found by Abdallah [42] in Egypt. The high levels of resistance to ampicillin were also in general agreement with many other studies [20, 43, 44].

However, unlike our results, Ozgumus and his colleagues [20] found that resistance to chloramphenicol was detected at low level (3\%), probably resulting from limited use of this drug in veterinary or human medicine there.

The situation was different in a study done by Sayah et al. [45] in Red Cedar watershed in Michigan, USA. Among 26 strains of E. coli isolated from surface water, all of them were sensitive to all tried antibiotics except for one of the cephalosporin to which $80.6 \%$ of isolates were resistant.

This variation in resistance pattern between different countries reflects human influence on the environment as it depends on the extent of consumption of a certain antibiotic in a community either in humans, in animals, or in agriculture. This also should pay our attention to the hazard of nonrationalized use of antibiotics which threatens us with an era of noneffective therapy against bacteria.

The relative extent of $E$. coli virulence genes appears to vary from one geographic area to another in environmental samples, asymptomatic carriers, or from diarrheal patients. Virulence genes are seen as perfect targets to distinguish the pathogenic potential of E. coli isolate [46]. However, the ability of these isolates to cause human diarrheal illness could not be established as this requires proper combination of virulence genes to cause disease [47].

In this study LT, ST, stx1, stx2, and eae genes were investigated among the isolated $E$. coli strains. eae gene was the one most frequently found (33.33\%) followed by $26.27 \%$ for LT gene; half of those contains also ST gene. stxl and stx2 genes were detected in a rate of $20.0 \%$ and $6.66 \%$, respectively.

Few studies were held to investigate these genes in drinking water. Kaper et al. found that only $3.9 \%$ isolates were positive for at least one gene which is lower than our study; however, the eae gene was the most prevalent, as in this study [48].

In India, Ram et al. [24] found that both stxl and stx2 genes were existing in $33.3 \%$ of isolates, and eae A gene was present in $100 \%$ of isolates.

In Brazil, out of 300 E. coli isolates, five were confirmed for presence of both stxl and stx 2 genes, two for stxl, and five for stx2 only. However, none of these STEC isolates carried eae gene [49].

In another study in Bangladesh, 16 (7\%) of E. coli isolates from household water supply sources owned virulence genes for EPEC and ETEC. Out of them 11 harbored LT and/or ST and only 5 had eae gene [50].

As the number of isolates was not enough to judge appropriately on the prevalence of these genes in our E. coli 
isolates, it is recommended to do further screening for serotypes and other virulence genes that may add more data on pathogenicity of $E$. coli isolated from environmental, animal, and human sources including rural areas of the city.

It could be concluded from this study that spreading the culture of antibiotic rationalization is an urgent requirement. Still, the problem of overpopulation and slums is an intractable problem which is reflected on all life aspects in poor developing countries. Another solution to decrease the rate of fecal contamination and hence diarrhea in such communities like renewal of the old water pipes in the city or building another water plant in the eastern side of city should be investigated.

\section{Competing Interests}

The authors have no competing interests to declare.

\section{Acknowledgments}

This work was funded by Zagazig University Academic Research Support Project (4th phase) and was also partially supported by Zagazig Scientific and Medical Research Laboratory. The authors' appreciation also should go to Mr. Mohammed Sayed, Geographical Researcher, Faculty of Literature, Benha University, and Dr. Rania Fouad Zonfoly, Resident Doctor, Ministry of Health and Population, Sharkia Governorate, for their great help.

\section{References}

[1] O. C. Shanks, J. W. S. Domingo, J. Lu, C. A. Kelty, and J. E. Graham, "Identification of bacterial DNA markers for the detection of human fecal pollution in water," Applied and Environmental Microbiology, vol. 73, no. 8, pp. 2416-2422, 2007.

[2] L. Liu, H. L. Johnson, S. Cousens et al., "Global, regional, and national causes of child mortality: an updated systematic analysis for 2010 with time trends since 2000," The Lancet, vol. 379, no. 9832, pp. 2151-2161, 2012.

[3] A. Jafari, M. M. Aslani, and S. Bouzari, "Escherichia coli: a brief review of diarrheagenic pathotypes and their role in diarrheal diseases in Iran," Iranian Journal of Microbiology, vol. 4, no. 3, pp. 102-117, 2012.

[4] N. A. Daniels, J. Neimann, A. Karpati et al., “Traveler's diarrhea at sea: three outbreaks of waterborne enterotoxigenic Escherichia coli on cruise ships," The Journal of Infectious Diseases, vol. 181, no. 4, pp. 1491-1495, 2000.

[5] M. Huerta, I. Grotto, M. Gdalevich et al., "A waterborne outbreak of gastroenteritis in the Golan Heights due to enterotoxigenic Escherichia coli," Infection, vol. 28, no. 5, pp. 267-271, 2000.

[6] P. R. Hunter, "Drinking water and diarrhoeal disease due to Escherichia coli," Journal of Water and Health, vol. 1, no. 2, pp. 65-72, 2003.

[7] F. Qadri, A.-M. Svennerholm, A. S. G. Faruque, and R. B. Sack, "Enterotoxigenic Escherichia coli in developing countries: epidemiology, microbiology, clinical features, treatment and prevention," Clinical Microbiology Reviews, vol. 18, no. 3, pp. 465-483, 2005.
[8] J. P. Nataro and J. B. Kaper, "Diarrheagenic Escherichia coli," Clinical Microbiology Reviews, vol. 11, no. 1, pp. 142-201, 1998.

[9] E. Brzuszkiewicz, A. Thürmer, J. Schuldes et al., "Genome sequence analyses of two isolates from the recent Escherichia coli outbreak in Germany reveal the emergence of a new pathotype: Entero-Aggregative-Haemorrhagic Escherichia coli (EAHEC)," Archives of Microbiology, vol. 193, no. 12, pp. 883891, 2011.

[10] C. J. Wu, P. R. Hsueh, and W. C. Ko, "A new health threat in Europe: Shiga toxin-producing Escherichia coli O104:H4 infections," Journal of Microbiology, Immunology and Infection, vol. 44, no. 5, pp. 390-393, 2011.

[11] World Health Organization (WHO), The World Health Report 2002, World Health Organization (WHO), Geneva, Switzerland, 2002.

[12] Bureau of Indian Standards (BIS), Indian Standard Specification for Drinking Water IS: 10500, Revised 2003, Indian Institute, New Delhi, India, 1991.

[13] M. W. Lechevallier, N. J. Welch, and D. B. Smith, "Full-scale studies of factors related to coliform regrowth in drinking water," Applied and Environmental Microbiology, vol. 62, no. 7, pp. 2201-2211, 1996.

[14] P. Payment, L. Richardson, J. Siemiatycki, R. Dewar, M. Edwardes, and E. Franco, "A randomized trial to evaluate the risk of gastrointestinal disease due to consumption of drinking water meeting current microbiological standards," American Journal of Public Health, vol. 81, no. 6, pp. 703-708, 1991.

[15] G. J. Kirmeyer, M. Friedman, K. Martel et al., Pathogen Intrusion into the Distribution System, AWWA Research Foundation and the American Water Works Association, Denver, Colo, USA, 2001.

[16] S. Folkman, Water Main Break Rates in the USA and Canada; A Comprehensive Study, Utah State University Buried Structures Laboratory, 2012, http://www.watermainbreakclock.com/docs/ UtahStateWaterBreakRates_FINAL_TH_Ver5lowrez.pdf.

[17] Water Corporation, "Management of water pipes," Western Australian Auditor General's Report, 2014.

[18] World Health Organization (WHO), Guidelines for DrinkingWater Quality, World Health Organization, Geneva, Switzerland, 4th edition, 2011.

[19] H. Hong, J. Qiu, and Y. Liang, "Environmental factors influencing the distribution of total and fecal coliform bacteria in six water storage reservoirs in the Pearl River Delta Region, China," Journal of Environmental Sciences, vol. 22, no. 5, pp. 663-668, 2010.

[20] O. B. Ozgumus, E. Celik-Sevim, S. Alpay-Karaoglu, C. Sandalli, and A. Sevim, "Molecular characterization of antibiotic resistant Escherichia coli strains isolated from tap and spring waters in a coastal region in Turkey," Journal of Microbiology, vol. 45, no. 5, pp. 379-387, 2007.

[21] S. Ram, P. Vajpayee, and R. Shanker, "Prevalence of multiantimicrobial-agent resistant, shiga toxin and enterotoxin producing Escherichia coli in surface waters of River Ganga," Environmental Science and Technology, vol. 41, no. 21, pp. 73837388, 2007.

[22] Clinical and Laboratory Standards Institute (CLSI), "Performance standards for antimicrobial susceptibility testing," in 22th Informational Supplement (CLSI M100-S22), Clinical and Laboratory Standards Institute, Wayne, Pa, USA, 2012.

[23] S. Zhao, D. G. White, B. Ge et al., "Identification and characterization of integron-mediated antibiotic resistance among 
shiga toxin-producing Escherichia coli isolates," Applied and Environmental Microbiology, vol. 67, no. 4, pp. 1558-1564, 2001.

[24] S. Ram, P. Vajpayee, U. Tripathi, R. L. Singh, P. K. Seth, and R. Shanker, "Determination of antimicrobial resistance and virulence gene signatures in surface water isolates of Escherichia coli, Journal of Applied Microbiology, vol. 105, no. 6, pp. 18991908, 2008.

[25] World Health Organization and UNICEF, Progress on Drinking Water and Sanitation: 2012 Update, WHO/UNICEF Joint Monitoring Programme for Water Supply and Sanitation, New York, NY, USA, 2012.

[26] C. B. Patel, P. Vajpayee, G. Singh, R. S. Upadhyay, and R. Shanker, "Contamination of potable water by enterotoxigenic Escherichia coli: qPCR based culture-free detection and quantification," Ecotoxicology and Environmental Safety, vol. 74, no. 8, pp. 2292-2298, 2011.

[27] S. Ram, P. Vajpayee, P. D. Dwivedi, and R. Shanker, "Culture-free detection and enumeration of STEC in water," Ecotoxicology and Environmental Safety, vol. 74, no. 4, pp. 551-557, 2011.

[28] R. Abu-Elyazeed, T. F. Wierzba, A. S. Mourad et al., "Epidemiology of enterotoxigenic Escherichia coli diarrhea in a pediatric cohort in a periurban area of lower Egypt," The Journal of Infectious Diseases, vol. 179, no. 2, pp. 382-389, 1999.

[29] M. Cheesbrough, District Laboratory Practice in Tropical Countries, 2nd edition, 2006.

[30] A. Rompré, P. Servais, J. Baudart, M.-R. De-Roubin, and P. Laurent, "Detection and enumeration of coliforms in drinking water: current methods and emerging approaches," Journal of Microbiological Methods, vol. 49, no. 1, pp. 31-54, 2002.

[31] H. Steinsland, P. Valentiner-Branth, M. Perch et al., "Enterotoxigenic Escherichia coli infections and diarrhea in a cohort of young children in Guinea-Bissau," The Journal of Infectious Diseases, vol. 186, no. 12, pp. 1740-1747, 2002.

[32] M. R. Rao, R. Abu-Elyazeed, S. J. Savarino et al., "High disease burden of diarrhea due to enterotoxigenic Escherichia coli among rural Egyptian infants and young children," Journal of Clinical Microbiology, vol. 41, no. 10, pp. 4862-4864, 2003.

[33] M. J. Albert, S. M. Faruque, A. S. G. Faruque et al., "Controlled study of Escherichia coli diarrheal infections in Bangladeshi children," Journal of Clinical Microbiology, vol. 33, no. 4, pp. 973-977, 1995.

[34] F. Qadri, S. K. Das, A. S. G. Faruque et al., "Prevalence of toxin types and colonization factors in enterotoxigenic Escherichia coli isolated during a 2-year period from diarrheal patients in Bangladesh," Journal of Clinical Microbiology, vol. 38, no. 1, pp. 27-31, 2000.

[35] M. G. Rowland, “The Gambia and Bangladesh: the seasons and diarrhoea," Dialogue on Diarrhoea, vol. 26, article 3, 1986.

[36] N. F. Col and R. W. O'Connor, "Estimating worldwide current antibiotic usage: report of task force 1," Reviews of Infectious Diseases, vol. 9, supplement 3, pp. S232-S243, 1987.

[37] N. Mezrioui and B. Baleux, "Resistance patterns of E. coli strains isolated from domestic sewage before and after treatment in both aerobic lagoon and activated sludge," Water Research, vol. 28, no. 11, pp. 2399-2406, 1994.

[38] R. J. Ash, B. Mauck, and M. Morgan, "Antibiotic resistance of gram-negative bacteria in rivers, United States," Emerging Infectious Diseases, vol. 8, no. 7, pp. 713-716, 2002.

[39] F. F. Reinthaler, J. Posch, G. Feierl et al., "Antibiotic resistance of E. coli in sewage and sludge," Water Research, vol. 37, no. 8, pp. 1685-1690, 2003.
[40] T. Schwartz, W. Kohnen, B. Jansen, and U. Obst, "Detection of antibiotic-resistant bacteria and their resistance genes in wastewater, surface water, and drinking water biofilms," FEMS Microbiology Ecology, vol. 43, no. 3, pp. 325-335, 2003.

[41] S. Toroglu, S. Dincer, and H. Korkmaz, "Antibiotic resistance in Gram-negative bacteria isolated from Aksu River in (Kahramanmaras) Turkey," Annals of Microbiology, vol. 55, pp. 229233, 2005.

[42] S. A. Abdallah, "Detection and differentiation of Escherichia coli populations from human, animal and avian feces, and different water sources," Polish Journal of Environmental Studies, vol. 14, no. 5, pp. 639-646, 2005.

[43] S. R. Andersen and R.-A. Sandaa, "Distribution of tetracycline resistance determinants among gram-negative bacteria isolated from polluted and unpolluted marine sediments," Applied and Environmental Microbiology, vol. 60, no. 3, pp. 908-912, 1994.

[44] P. I. Boon and M. Cattanach, "Antibiotic resistance of native and faecal bacteria isolated from rivers, reservoirs and sewage treatment facilities in Victoria, south-eastern Australia," Letters in Applied Microbiology, vol. 28, no. 3, pp. 164-168, 1999.

[45] R. S. Sayah, J. B. Kaneene, Y. Johnson, and R. A. Miller, "Patterns of antimicrobial resistance observed in Escherichia coli isolates obtained from domestic- and wild-animal fecal samples, human septage, and surface water," Applied and Environmental Microbiology, vol. 71, no. 3, pp. 1394-1404, 2005.

[46] P. Kuhnert, P. Boerlin, and J. Frey, "Target genes for virulence assessment of Escherichia coli isolates from water, food and the environment," FEMS Microbiology Reviews, vol. 24, no. 1, pp. 107-117, 2000.

[47] M. Halabi, D. Orth, K. Grif et al., "Prevalence of Shiga toxin-, intimin- and haemolysin genes in Escherichia coli isolates from drinking water supplies in a rural area of Austria," International Journal of Hygiene and Environmental Health, vol. 211, no. 3-4, pp. 454-457, 2008.

[48] J. B. Kaper, J. P. Nataro, and H. L. T. Mobley, "Pathogenic Escherichia coli," Nature Reviews Microbiology, vol. 2, no. 2, pp. 123-140, 2004.

[49] K. M. S. Lascowski, B. E. C. Guth, F. H. Martins, S. P. D. Rocha, K. Irino, and J. S. Pelayo, "Shiga toxin-producing Escherichia coli in drinking water supplies of north Paraná State, Brazil," Journal of Applied Microbiology, vol. 114, no. 4, pp. 1230-1239, 2013.

[50] P. K. Talukdar, M. Rahman, M. Rahman et al., "Antimicrobial resistance, virulence factors and genetic diversity of Escherichia coli isolates from household water supply in Dhaka, Bangladesh," PLoS ONE, vol. 8, no. 4, Article ID e61090, 2013. 

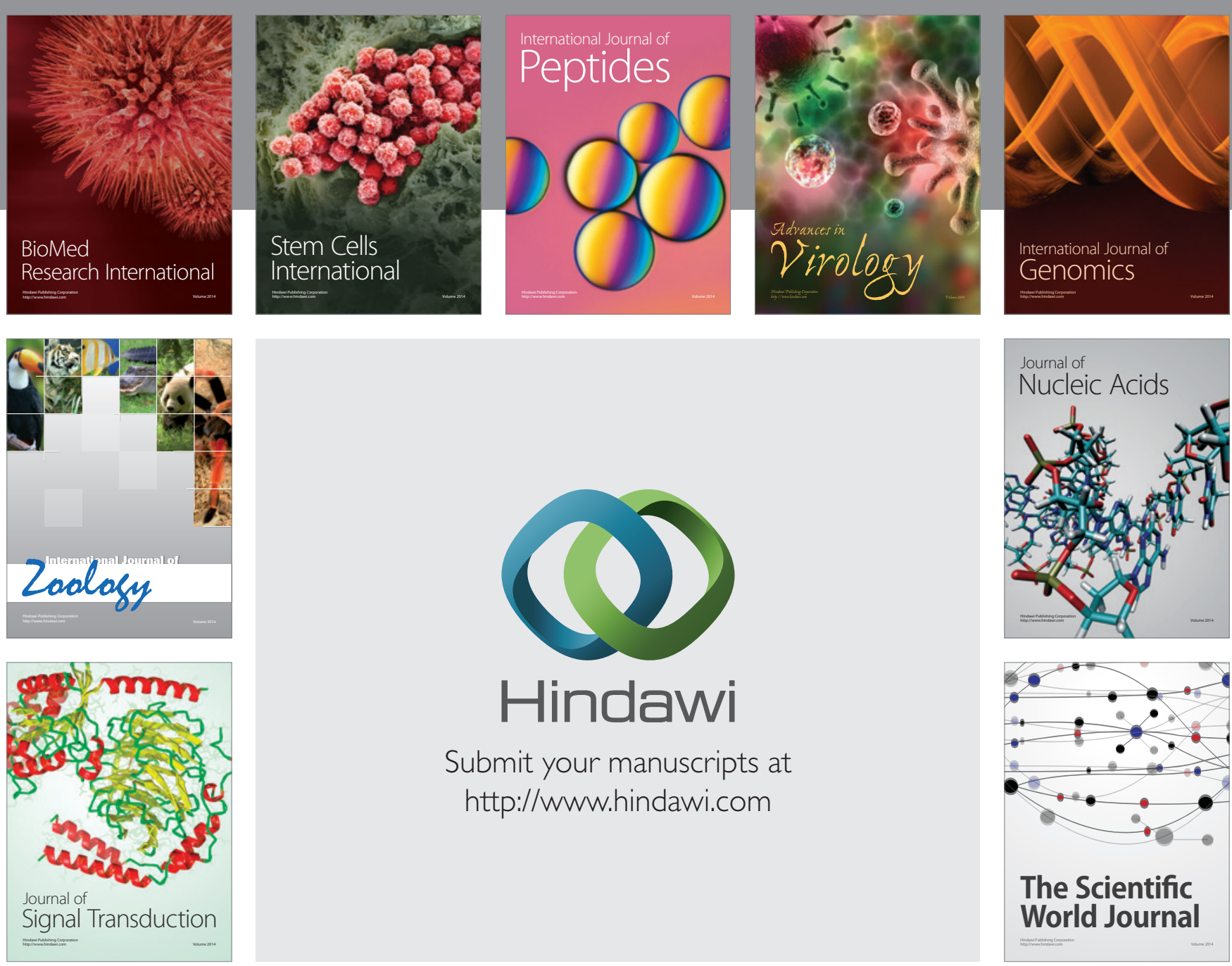

Submit your manuscripts at

http://www.hindawi.com
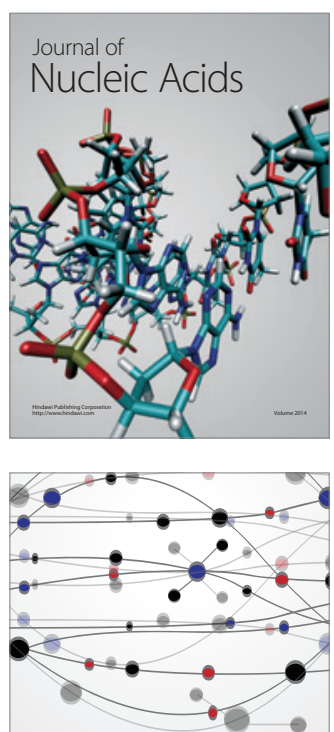

The Scientific World Journal
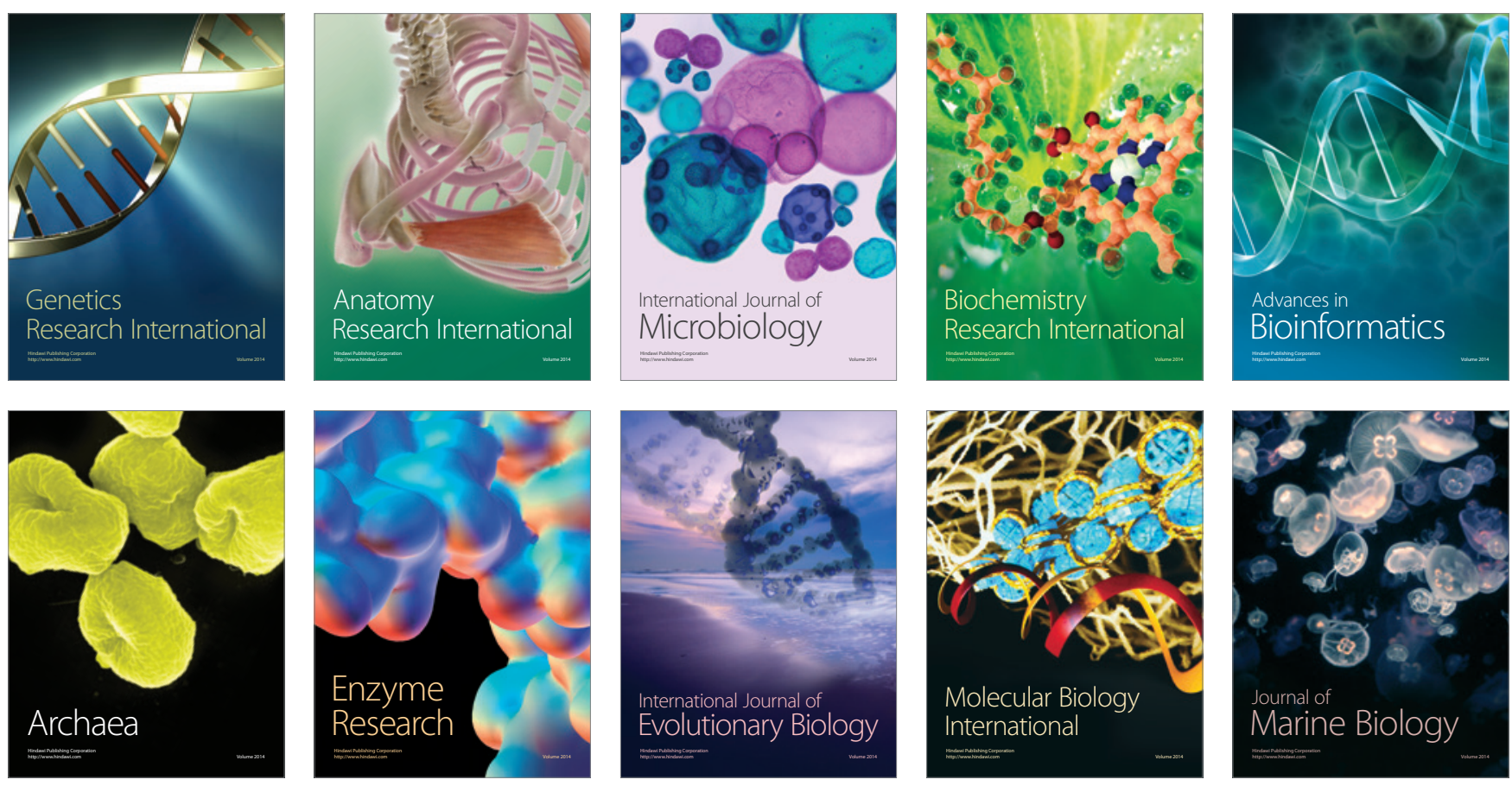